\title{
Islam and Global Dialogue: Religious Pluralism and the Pursuit of Peace
}

\author{
Roger Boase, ed. \\ Ashgate: Hants, 2005
}

If there were ever a time that a book on religious pluralism and peace ought to be required reading for politicians, public intellectuals, policymakers, and the media, as well as a general audience, that time is now. Conceived as a response to the excoriation of Islam after 9/11, Roger Boase has put together a remarkable book on the need for interreligous dialogue as the only way to "lay the foundations for a more peaceful world (p. xviii)." This need reverberates through each chapter, be it written by a Jewish, Christian, or Muslim scholar. This means that, as in a symphony, even though each scholar writes grounded in his/her own faith tradition (instrument), their collective voices chorus the same song. It makes for very powerful reading.

The book is divided into three parts, with a foreword on the importance of bridge building between cultures by HRH Prince Hassan bin Talal, the former crown prince of Jordan, a preface and an introduction by Boase, and a postscript by author Wendell Berry on the failure of war as a way to secure peace. After initially considering inviting scholars from all faith traditions to contribute, Boase decided there was not space in a single volume to do this in an adequate way. Therefore, the book focuses on contributions from scholars from the three Abrahamic faith traditions: Judaism, Christianity, and Islam. He rightly says that this gives the book a tighter focus. Given the importance of the West/Islamic civilizational divide these days, it is important to have a book that focuses on these faith traditions. From a wider, global perspective, though, this may limit its potentially positive impact about the need for interreligous dialogue only to those readers who identify with one of the three Abrahamic faiths. Muslims in China, for instance, would need to appeal to whole different discourses in order to establish the need for constructive Sino-Muslim dialogue for peace.

Part One, "Defining the Issue," has articles from three scholars who try to set the terms of the discourse: John Bowden talks about the Enlighten- 
ment's ever-present backdrop and how its rational and critical approach to religion has affected and engendered a modern need for religious dialogue. On page 23, Diana Eck defines the different responses to the reality of religious diversity: exclusivism (our tradition is the one and only truth, excluding all others), inclusivism (there are many traditions, but ours is the culmination of or superior to all others), and pluralism (no one tradition has a monopoly on truth, and we can learn from each other without giving up our own commitments). Muhammad Legenhausen, a convert to Islam, theorizes a nonreductive approach to religious pluralism from an Islamic perspective.

Part Two, "Islam and the West: Clash or Dialogue," features three Muslim and five non-Muslim scholarly responses that address, either directly or indirectly, Huntington's infamous "clash of civilizations" theory and the tragic events of 9/11. Their overarching theme is that there is no essentialized clash between "Islam" and "the West." The concluding remarks of Robert Dickson Crane, a convert to Islam, are echoed throughout by the various authors: "Only through mutual self-understanding in interfaith dialogue can we undergo the mutual transformation that expands our own identity, and only through such transformation can we successfully promote mutual cooperation as a catalyst for justice (p. 177)." Part Three, "Jewish, Christian, and Muslim Responses to Religious Diversity," features two Jewish, two Christian, and four Muslim responses exploring what it means to be committed adherents to their own faith tradition while seeking to respect those of other faith traditions or how, in the words of Anglican vicar Marcus Braybrooke, to "learn to see members of other faiths as fellow pilgrims" while remaining a "witness to one's experience of divine mercy (p. 225)."

Thirteen of the twenty essays are reprints from earlier publications or lectures. In general this works well, although I felt that the section on "Islam and the West" had too many reprints. A lot has happened since those essays were first published, and I had a sense, albeit ever so slight, that some of them were dated, especially those that were originally written in the immediate aftermath of 9/11 - an event that, incredible as it may seem, five years later has subsequently been overshadowed by other crises, such as the war on Iraq, the 2006 Danish cartoon controversy, and the Israeli invasion of Lebanon, to name but a few.

Having said that, I can see how hard it would have been for Boase to cut any chapter. As I read each chapter, I thought to myself that "this is the best chapter of the book." Dealing with religious pluralism, a topic that touches the most important facets of life (e.g., the big questions about "Why am I here?" and "What's it all about?"), the book has a depth to it that is profound and moving. And given that Islam has become widely perceived as a reli- 
gion of hate and intolerance, a volume such as this one, which highlights Islam's positive contribution to interfaith dialogue, is exceedingly important.

Katherine Bullock AJISS Editor Missassagua, Ontario, Canada 